\title{
A victory for genes
}

\section{The ability to patent human genes has been costly to researchers and patients, and has restricted competition in the biotech marketplace. The recent US Supreme Court decision making isolated human genes unpatentable will bring freedom of choice to the patient, and level the playing field for research and development.}

$\mathbf{O}$ n 13 June, in a landmark decision, the US Supreme Court ruled that human genes cannot be patented. The unanimous decision by the Court concludes a lawsuit against the molecular diagnostics company Myriad Genetics that was seeking to invalidate certain claims in three of the company's US patents on the $B R C A 1$ and $B R C A 2$ genes, which were originally granted in the 1990 s. This welcome ruling marks the first time that the US Supreme Court has invalidated a human gene patent.

The decision has been a long time in coming-so long that Myriad's patents were due to expire in less than three years. And the 15-year delay has surely not aided patients who frequently benefit from healthy competition in the biotech sector or from research on $B R C A$ genes. Yet the decision brings relief to those of us who reject the idea that an individual or corporation can own-even for a limited timehuman genes and thereby control their use.

In 1994, Mark Skolnick, a future founder of Myriad Genetics, along with several other research groups, cloned $B R C A 1$, followed swiftly by BRCA2. Myriad Genetics was founded that same year, and the company filed patents for the two genes in 1994 and 1995. Mutations in the genes are associated with increased susceptibility to breast and ovarian cancers, and Myriad has successfully translated this information into genetic testing kits. Moreover, by claiming intellectual property rights on these genes, they have precluded other companies and university-based diagnostic labs from commercializing competing tests, effectively establishing a monopoly on $B R C A$ testing.

But in 2009, the American Civil Liberties Union and the Public Patent Foundation filed a lawsuit against Myriad Genetics, the US Patent and Trademark Office and others, stating that patenting BRCA1 and BRCA2 was unconstitutional. After several rounds in lower courts, with alternating decisions in favor of and against the motion, the Supreme Court agreed in November 2012 to hear the case (Association for Molecular Pathology et al. v. Myriad Genetics, Inc., et al.).

In siding with the plaintiffs in this case, the Court's decision rests on the interpretation of a section of the US Code governing patent law that has remained virtually unchanged since 1793. According to the Code, "any new or useful process, machine, manufacture or composition of matter, or any new and useful improvement thereof" can be patented. Although not explicitly stated, the wording has been interpreted to mean that naturally occurring phenomena are not new or invented and therefore are not inherently patentable. In writing the Court's opinion, Justice Clarence Thomas stated, "Myriad did not create or alter any of the genetic information encoded in the BRCA1 and $B R C A 2$ genes. The location and order of the nucleotides existed in nature before Myriad found them. Nor did Myriad create or alter the genetic structure of DNA .... We ... hold that genes and the information they encode are not patent eligible ... simply because they have been isolated from the surrounding genetic material." (http://www. supremecourt.gov/opinions/12pdf/12-398_1b7d.pdf).

Although clearly concluding that naturally occurring genes (isolated or not) are not patentable, the Court nevertheless indicated that cDNA is patent eligible, a decision that has led to at least one commentary questioning the scientific basis of that decision (http://www.bloomberg. com/news/2013-06-13/the-supreme-court-s-bad-science-on-genepatents.html/). Granted, cDNA is not naturally occurring and, if made from mRNA, is an altered form of the intact gene, as it excludes introns. But the sequence of cDNA is dictated by the sequence of its template mRNA or DNA. Given that the Court concluded that Myriad did not alter the genetic information of the isolated $B R C A$ genes, and if cDNA does not alter the information encoded by the cellular mRNA (or DNA), shouldn't the same decision on patent eligibility apply to cDNA?

Nevertheless, companies seeking to develop genetic tests of $B R C A$ genes do not seem perturbed that the cDNA might be patent protected. There are many ways in which a genetic sequence can be analyzed, and therefore a patent claim on a cDNA can be easily sidestepped. Moreover, new technology and cheaper genomic sequencing may eventually obviate the need to employ cDNA in gene testing. Interestingly, the Court's decision stated that not all cDNAs would be patent eligible, as those originally derived from DNA without introns might not be. That qualification could specifically affect patents on bacterial or viral cDNAs, which would extend the decision's reach.

Thus, the full impact of the Court's ruling has yet to be felt. A recent analysis published in Nature Biotechnology concluded that about 8,000 patents involving genes-and, of these, 3,500 involving human genes-would probably be invalidated by the Court's decision (Nat. Biotechnol. 31, 404-410, 2013). However, the number of US patent applications involving human genes has declined since its peak in 1999, and in 2001 the US Patent Office revised its examination guidelines to more explicitly require evidence of utility of an isolated gene in a patent application, thereby limiting the ability for someone to receive a patent on gene sequence alone. So, although the patent landscape will now be indelibly altered by this ruling, the effect on research and development could be modest.

Yet some pundits argue that invalidating patents on human genes will harm the biotech industry and reduce the incentive to develop new diagnostic tests, whereas others (including industry insiders) feel that enabling competition will result in more research and development, more tests on the market and lower prices for consumers. Myriad itself issued a statement saying that their patent claims that were not challenged in the lawsuit remained valid (or at least patent eligible) and protect the intellectual property underlying their $B R C A$ gene test-and ultimately their business model. With this ruling, the US Supreme Court has achieved an unusual situation-a win for science, for patients and for industry. Long may it last. 